Experimental Studies 


\title{
Biochemical Inhibition of DOG1/TMEM16A Achieves Antitumoral Effects in Human Gastrointestinal Stromal Tumor Cells In Vitro
}

\author{
ROBIN FRÖBOM ${ }^{1}$, FELIX SELLBERG ${ }^{2}$, CHENG XU $^{3}$, ALLAN ZHAO $^{3}$, CATHARINA LARSSON $^{4,5}$, \\ WENN-ONN LUI ${ }^{4,5}$, INGA-LENA NILSSON ${ }^{1}$, ERIK BERGLUND ${ }^{6}$ and ROBERT BRÄNSTRÖM ${ }^{1}$ \\ ${ }^{1}$ Department of Molecular Medicine and Surgery, Karolinska Institutet, Stockholm, Sweden; \\ ${ }^{2}$ Department of Immunology, Genetics and Pathology, Uppsala University, Uppsala, Sweden; \\ ${ }^{3}$ The Rolf Luft Center for Diabetes Research, Department of Molecular Medicine and Surgery, \\ Karolinska Institutet, Stockholm, Sweden; \\ ${ }^{4}$ Department of Oncology-Pathology, Karolinska Institutet, Stockholm, Sweden; \\ ${ }^{5}$ Cancer Center Karolinska, Karolinska University Hospital, Stockholm, Sweden; \\ ${ }^{6}$ Division of Transplantation Surgery, CLINTEC, Karolinska Institute, and \\ Department of Transplantation Surgery, Karolinska University Hospital, Stockholm, Sweden
}

\begin{abstract}
Background/Aim: DOG1 is a calcium-activated chloride channel that has gained attention as a promising drug target due to its involvement in several processes essential for tumor development and progression. DOG1 is overexpressed in $>95 \%$ of gastrointestinal stromal tumors (GIST). The aim was to determine DOG1 inhibition antitumoral effects on GIST. Materials and Methods: Human GIST (GIST-T1 and GIST882) cell lines were used to study the effect of DOG1 inhibitors on chloride currents, viability, colony formation, and cell cycle. Results: $\mathrm{CaCC}_{i n h^{-}} \mathrm{AO1}$ decreased chloride currents. $\mathrm{CaCC}_{i n h^{-}}$ A01 and $\mathrm{Tl}_{\text {inh }}{ }^{-\mathrm{A} O 01}$ reduced GIST cell viability and $\mathrm{CaCC}_{\text {inh }}{ }^{-}$ A01 affected cell cycle distribution leading to $G_{1}$ cell-cycle arrest. $\mathrm{CaCC}_{\text {inh }}$-AO1 also increased the sub-G $G_{1}$ phase population, indicative of apoptosis, in GIST882. $\mathrm{CaCC}_{\text {inh }}$-AOI strongly reduced the colony forming ability of the cells, whereas $T 16_{i n h}-A 01$ did not. Conclusion: DOG1 inhibition has antitumoral effects in GIST cells in vitro, and could potentially serve as a target for GIST therapy.
\end{abstract}

Gastrointestinal stromal tumor (GIST) is of mesenchymal origin and is the most common soft tissue sarcoma (1). In

This article is freely accessible online.

Correspondence to: Robin Fröbom, Endocrine and Sarcoma Surgery Unit, Department of Molecular Medicine and Surgery, Karolinska Institutet, Karolinska University Hospital L1:03, SE-171 76 Stockholm, Sweden, E-mail: robin.frobom@ki.se

Key Words: Gastrointestinal stromal tumors, GIST, DOG1, TMEM16A, ion channel, cancer. most cases, it is characterized by gain-of-function mutations in genes coding for receptor tyrosine kinases (e.g. KIT and PDGFRA) (2). Current medical treatment is targeting this mutated receptor with tyrosine kinase inhibitors, and this has greatly improved the survival in GIST (3). Discovered-onGIST-1 (DOG1) and synonymous with TMEM16A and ANO1, belongs to the group of calcium-activated chloride channels (CaCCs) and has proven to be an important diagnostic marker due to its expression in $>95 \%$ of GISTs (4). The gene, ANO1, coding for the DOG1 protein is located in a commonly amplified region of the long arm of chromosome 11 (11q13.3) in human cancers (5). DOG1 has not been found to be mutated in GIST (6), however, DOG1 is expressed in interstitial cells of Cajal (7), which is the proposed progenitor cell of GIST (2).

$\mathrm{CaCCs}$ are expressed in a variety of tissues and are essential regulators of normal physiological functions, including neuronal excitability, smooth muscle cell contraction, epithelial fluid secretion, and gastrointestinal motility (8). Specifically, DOG1 has been shown to be a voltage-sensitive and ligand-activated ion channel that is activated by increased intracellular free $\mathrm{Ca}^{2+}\left(\left[\mathrm{Ca}^{2+}\right]_{\mathrm{i}}\right)(9)$. Increasing evidence suggests that DOG1 is involved in tumorigenesis, cancer progression, metastasis, and cell survival. It has been studied in several tumors of epithelial origin such as: i) breast (10-13), ii) lung (14), iii) colon (15, 16), iv) head and neck (17-19), v) gastric (20), vi) glioma (21), and vii) prostate $(22,23)$. The reported effects have been conflicting, and several mechanisms have been proposed. Signaling pathways of relevance are EGFR and CAMKII $(13,24)$, MAPK (17), TGF- $\beta$ (25), and NF-kB (21), which seem to be cell-specific. A recent study showed that the apoptosis signaling pathway 
activated through TNF- $\alpha$ was similar between the knockdown model and a biochemical inhibition (23). In GIST, high DOG1 expression is associated with poor prognosis and its high levels in circulating tumor cells can predict recurrence (26). The functional role of DOG1 is not fully understood, with only two studies having examined its role in GIST to date. The first used either DOG1 knockdown or biochemical inhibition. Using the knockdown approach resulted in decreased growth rate in the GIST xenografts in vivo, while no effect on cell growth was seen in vitro by either DOG1 knockdown or biochemical inhibition (27). The second study by our group

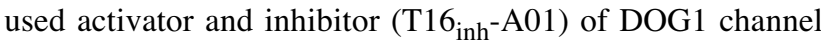
and studied several cell biological properties in an in vitro setting, and determined that DOG1 inhibition induces apoptosis in an imatinib-resistant cell line (28). In a study using several epithelial tumor cell lines, it was discovered that DOG1 degradation was crucial for its antitumoral effects (29). Since then, advancements have been made in the knowledge of $\mathrm{CaCC}$ inhibitors possessing not only inhibitory activities but also DOG1 protein degradation properties, reviewed in detail elsewhere (30). Therefore, we sought to evaluate if enhanced DOG1 inhibition would lead to functional antitumoral effects in well-established GIST tumor cell lines.

\section{Materials and Methods}

Cell lines. GIST-T1 (Cosmo Bio Co. Ltd., Tokyo, Japan) and GIST882 are two human GIST cell lines. GIST-T1 were maintained in Dulbecco's Modified Eagle Medium (DMEM) supplemented with 10\% fetal bovine serum (FBS), $1 \%$ Glu-Max, 1\% Penicillin-Streptomycin. GIST882 cells were maintained in DMEM, 15\% FBS, $1 \%$ Glu-Max, $1 \%$ Penicillin-Streptomycin. Cells were incubated in $37^{\circ} \mathrm{C}$ with $5 \%$ $\mathrm{CO}_{2}$. Reagents for medium were purchased from Sigma-Aldrich (Sigma-Aldrich, MO, USA). Both cell lines have been shown to express DOG1 (27). GIST882 cell line was a kind gift from professor Jonathan A. Fletcher, Brigham Women's Hospital (MA, USA).

Reagents. Two inhibitors were used to modulate channel activity. $\mathrm{T}_{16}{ }_{\mathrm{inh}}$-A01 (Sigma-Aldrich) has previously been shown to reduce chloride currents by up to $60 \%$ at a concentration of $30 \mu \mathrm{M}$ in GIST cells (28). $\mathrm{CaCC}_{\text {inh }}$-A01 (Sigma-Aldrich) has been shown to reduce chloride currents in DOG1 expressing cells (29). E-act (SigmaAldrich) was used to activate the chloride channel in patch-clamp experiments only. Stock solutions were dissolved in dimethyl sulfoxide (DMSO) yielding stock solutions of $10 \mathrm{mM}$. Solvent (DMSO) was used as a control, and concentrations never reached $>0.3 \%$ ( $\mathrm{vol} / \mathrm{vol})$.

Electrophysiology. Whole-cell CaCC currents were recorded using the patch-clamp technique (31) and a HEKA EPC-10 patch-clamp amplifier (HEKA Elektronik, Germany). Current traces were shown according to the convention that up-ward deflection denotes inward currents, using extracellular solution (i.e. bath solution) contained: i) $150 \mathrm{mM} \mathrm{NaCl}$, ii) $1 \mathrm{mM} \mathrm{MgCl}_{2}$, iii) $1 \mathrm{mM} \mathrm{CaCl}_{2}$, iv) $10 \mathrm{mM}$ Glucose, v) $10 \mathrm{mM}$ Mannitol and vi) $10 \mathrm{mM}$ Na-HEPES (pH 7.4). The pipette (i.e. intracellular) solution contained: i) $130 \mathrm{mM} \mathrm{CsCl}$, ii) $1 \mathrm{mM}$ $\mathrm{MgCl}_{2}$, iii) $10 \mathrm{mM}$ HEPES, and iv) $1 \mathrm{mM}$ ATP (pH 7.4 using CsOH).
$\mathrm{CaCl}_{2}$ and EGTA were added to the pipette solution to obtain the desired free $\mathrm{Ca}^{2+}$-concentration, $\left[\mathrm{Ca}^{2+}\right]_{\text {pip }}$ : i) $8 \mathrm{mM} \mathrm{CaCl}_{2}$ and 10 mM EGTA for $305 \mathrm{nM}$, and ii) $8 \mathrm{mM} \mathrm{CaCl}_{2}$ and $12 \mathrm{mM}$ EGTA for $90 \mathrm{nM}$ (calculated with MaxChelator software version 1.3 developed by Dr. Chris Patton, Stanford University, USA, http://maxchelator. stanford.edu). In all whole-cell recordings, series resistance $\left(R_{S}\right)$ was $<40 \mathrm{M} \Omega$, and cell capacitance was updated between every voltageprotocol cycle. All experiments were performed at room temperature, approximately $+22^{\circ} \mathrm{C}$, and cells were voltage-clamped at $-80 \mathrm{mV}$ and subsequently depolarized for $600 \mathrm{~ms}$ in $+20 \mathrm{mV}$ steps until $+80 \mathrm{mV}$. Pipettes were pulled from borosilicate using a P-2000 laser pipette puller (Sutter Instruments, Novato, CA, USA) and had resistances between 2 and $4 \mathrm{M} \Omega$. Records were filtered at $2.1 \mathrm{kHz}$ and digitized at $10 \mathrm{kHz}$. Mean whole-cell current was calculated for each voltagestep between $100 \mathrm{~ms}$ after voltage-pulse started, and $100 \mathrm{~ms}$ prior to voltage-pulse ended.

Cell viability assay. Cells were seeded in 96-well plates at a concentration of $0.5 \times 10^{4}$ cells per well followed by incubation overnight to allow adherence. Twenty-four hours later cells were treated with each compound respectively or DMSO as a control, at these time points: i) $24 \mathrm{~h}$, ii) $48 \mathrm{~h}$, and iii) $72 \mathrm{~h}$. CellTiter-Glo (Promega, WI, USA), an ATP-based luminometric method, was used to determine cell viability, according to manufacturer's protocol. In short, cells were taken out from incubator, $100 \mu \mathrm{L}$ of CellTiter-Glo reagent at room temperature were added into each well, and the plate was put on a shaker for 15 -minutes and was left to stabilize for 5-10 minutes before the readout. For subsequent analysis, all values were normalized to control. Readout was done using GloMax 96 Microplate Luminometer (Promega).

Cell cycle analysis. Cells were seeded at a density of $1 \times 10^{5}$ in 6well plates and were left to adhere overnight. Drugs, or DMSO, were added to each well and were incubated for 48 hours. Following treatment, adherent cells were washed with PBS twice, were harvested and subsequently fixed in $70 \%$ cold ethanol. Cells were fixed at $4^{\circ} \mathrm{C}$ for at least $2 \mathrm{~h}$, they were then washed and incubated for 30 minutes in propidium iodide (PI) staining buffer $(10 \mu \mathrm{g} / \mathrm{ml}$ PI and RNase A $100 \mu \mathrm{g} / \mathrm{ml}$, Sigma-Aldrich) at room temperature. Cytometry was performed using a FACSverse flow cytometer (BD Biosciences, San Jose, CA, USA). Data were analyzed using Flow Jo software and cell cycle analysis was done using a built-in tool with Watson (pragmatic) univariate model. Experiments were performed in triplicates.

Colony Formation assay. GIST-T1 cells were seeded in 12-well plates with approximately 1,000 cells/well. Cells were incubated overnight to allow adhering, after which cells were treated with the DOG1 inhibitory compounds. No media change occurred during the 10-14 days of the experiment. After 10-14 days, cells were fixed and stained using a solution of $4 \%$ phosphate-buffered formaldehyde with $0.5 \%$ crystal violet (wt/vol). Well plates were scanned using LI-COR Odyssey CLx scanner with subsequent quantification of each well in Image Studio LI-COR software (both from LI-COR Biosciences, NE, USA).

Statistical analysis. All data are presented as mean \pm standard error of the mean (SEM) unless otherwise stated. Experiments were done in at least triplicates unless otherwise stated. For electrophysiology, $t$-test was used. For the viability assay, two-way 
ANOVA was used with Tukey's test for multiple comparisons. For the cell cycle analysis, two-way ANOVA and post-hoc analysis using Dunnett's test were implemented. For the sub- $\mathrm{G}_{1}$ analysis, Kruskal-Wallis test was used with Dunn's test for multiple comparisons. For the colony formation assay, one-way ANOVA with Dunnett's test for multiple comparisons was used. A $p$-Value of less than 0.05 was considered to be statistically significant. All analyses were performed using GraphPad Prism software 7.0 (GraphPad Software Inc., SD, CA, USA).

\section{Results}

The inhibitor $\mathrm{CaCC}_{\text {inh }}$-A01 reduces chloride currents in GIST cells. To assess chloride currents, we used the patch-clamp technique in single cells (Figure 1). Exposure of the compound $\mathrm{CaCC}_{\text {inh }}$-A01 $(30 \mu \mathrm{M})$ resulted in decreased currents of approximately $50 \%$ (Figure $1 \mathrm{~A}$ and $\mathrm{B}$ ). At $+80 \mathrm{mV}$, the mean current decreased from $399.1 \pm 35$ to $164.4 \pm 8 \mathrm{pA}(p<0.01, \mathrm{n}=4)$. $\mathrm{CaCC}_{\text {inh }}$-A01 showed a dose-dependent inhibition of chloride currents, and $69.8 \pm 45.2 \%(\mathrm{n}=3)$ activation by DOG1-activator (E-act) (Figure 1C). Following washout, chloride currents increased (Figure 1E). Significant difference was observed following exposure of $30 \mu \mathrm{M} \mathrm{CaCC} \mathrm{inh}$-A01. In experiments where pipette solutions contained $90 \mathrm{nM}$ of $\left[\mathrm{Ca}^{2+}\right]_{\text {pip }}$, low chloride currents could be observed, but none were activated by E-act $30 \mu \mathrm{M}$ (Figure 1D).

DOG1 inhibition leads to decreased cell viability in GIST cells. GIST cells were treated for 24,48 , or $72 \mathrm{~h}$ before measurement of cell viability expressed by the percentage of control. Both $\mathrm{CaCC}_{\mathrm{inh}}-\mathrm{A} 01$ and $\mathrm{T} 16_{\text {inh }}-\mathrm{A} 01$ treated cells showed decreased viability as compared to DMSO-control (Figure 2). At time point $72-\mathrm{h}$, both cell lines showed reduced viability at $30 \mu \mathrm{M}$ of $\mathrm{CaCC}_{\mathrm{inh}}-\mathrm{A} 01$ or $\mathrm{T} 16_{\mathrm{inh}}-\mathrm{A} 01$. In GIST-T1 cells, $\mathrm{CaCC}_{\mathrm{inh}} \mathrm{A} 01(30 \mu \mathrm{M})$ reduced their viability to $70 \%$ compared to control $(p<0.0001)$, while T16 inh A01 $(30 \mu \mathrm{M})$ reduced it to $64 \%$ compared to control $(p<0.0001)$. In GIST882 cells, $30 \mu \mathrm{M}$ of $\mathrm{CaCC}_{\text {inh- }}-\mathrm{A} 01$ reduced cell viability to $66 \%$ compared to control $(p<0.0001)$ and $\mathrm{T}_{16} 6_{\text {inh }^{-}} \mathrm{A} 01$ reduced it to $88 \%(\mathrm{p}=0.012)$. Similar effects were observed between the two cell lines using $\mathrm{CaCC}_{\text {inh }}$-A01, however, $\mathrm{T}_{16} 6_{\text {inh }}$-A01 was more potent in GIST-T1 (Figure 2E).

DOG1 inhibition decreases colony formation. To assess the long-term effects of DOG1 inhibition, a colony formation assay was used. GIST-T1 showed a distinct decreased colony formation ability following $\mathrm{CaCC}_{\mathrm{inh}}$-A01 treatment compared to $\mathrm{T}_{16}{ }_{\text {inh }} \mathrm{A} 01$ (Figure $\left.1 \mathrm{~A}\right)$. For $\mathrm{CaCC}_{\text {inh }}-\mathrm{A} 01$ treated cells, significantly reduced ability of GIST-T1 cells to form colonies was observed for concentrations over $3 \mu \mathrm{M}$ compared to control (Figure 3B), with $5 \mu \mathrm{M}(p<0.05), 10 \mu \mathrm{M}$ $(p<0.001)$, and $30 \mu \mathrm{M}(p<0.0001)$. In $\mathrm{T} 16_{\mathrm{inh}} \mathrm{A} 01$ treated cells, no significant difference was found (Figure $3 \mathrm{C}$ ).

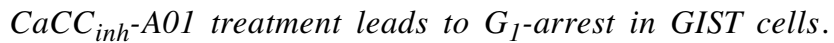
Adherent cells were used for cell cycle analysis after 48-hour treatment with $\mathrm{CaCC}_{\text {inh }}$-A01 or $\mathrm{T}_{16} 6_{\text {inh }}$-A01 (Figure 4). In GIST-T1, CaCC inh -A01 changed the cell cycle distribution of the populations significantly compared to both $\mathrm{T}_{16} 6_{\text {inh }^{-}} \mathrm{A} 01$ treated cells and DMSO control. Cells treated with $\mathrm{CaCC}_{\mathrm{inh}^{-}}$ A01 were arrested in $\mathrm{G}_{1}$-phase, with a $6 \%$ increase of cells in $\mathrm{G}_{1}$-phase with $10 \mu \mathrm{M}(p<0.01)$ and $10 \%$ increase of cells in $\mathrm{G}_{1}$-phase with $30 \mu \mathrm{M}(p<0.001)$ compared to control. $\mathrm{T}_{16} 6_{\text {inh }}$-A01 showed no statistically significant difference in the distribution of the populations compared to control (Figure 4E). In GIST882, $\mathrm{G}_{1}$ cell cycle arrest was also noted in $\mathrm{CaCC}_{\text {inh }}$-A01, but not in $\mathrm{T}_{16} 6_{\text {inh }}$-A01 treated cells (Figure $4 \mathrm{~F}$ ), corresponding to an increase of $6 \%$ in $\mathrm{G}_{1}$-phase for both concentrations, respectively, compared to control. In GIST882 cells, a sub-G $\mathrm{G}_{1}$ population corresponding to apoptotic cells, was significantly increased in $30 \mu \mathrm{M}$ with 6$7 \%$ showing signs of apoptosis $(p<0.05$, Figure 4D), whereas in $10 \mu \mathrm{M}$ and in the control no statistically significant changes were observed, and sub- $\mathrm{G}_{1}$ population ranged between $2-3 \%$. This sub- $\mathrm{G}_{1}$ fraction (Figure $4 \mathrm{~B}$ ) of cells were excluded from the cell cycle analysis, to allow comparison between viable cells capable of undergoing mitosis, with $100 \%$ viable portion present only in $G_{0} / G_{1}, S$, and $G_{2} / M$ phases. No significant sub- $G_{1}$ population was observed in GIST-T1.

\section{Discussion}

GIST is the most common human sarcoma in the abdominal cavity, with an incidence of about 15 per million patients/year. Since the introduction of tyrosine kinase inhibitor treatment little more than 15 years ago, tumor-specific survival has improved dramatically (3). However, the majority of patients develop resistance over time, and additional treatment strategies are a prioritized field in the GIST research area.

DOG1 has, ever since its discovery in GIST, been a reliable diagnostic marker due to its strong expression in GIST, with more than $95 \%$ positive specimens, regardless of the receptor tyrosine kinase mutational status (4). Functionally DOG1 belongs to the group of $\mathrm{CaCCs}$, which are essential in a range of physiological processes, including cell volume regulation, smooth muscle cell signaling and neuronal signaling (8). In tumors of epithelial origin, DOG1 has become increasingly studied due to its involvement in several pathophysiological processes that are crucial for tumor development and progression (32).

Since DOG1 is abundantly expressed in GIST, the hypotheses have been that it would work as a therapeutic target. Two studies have examined this question, both failing to show antitumoral effects of DOG1 modulation in vitro. The first study by Simon et al., has examined its role both in a cell line and a xenograft model, using a knockdown 

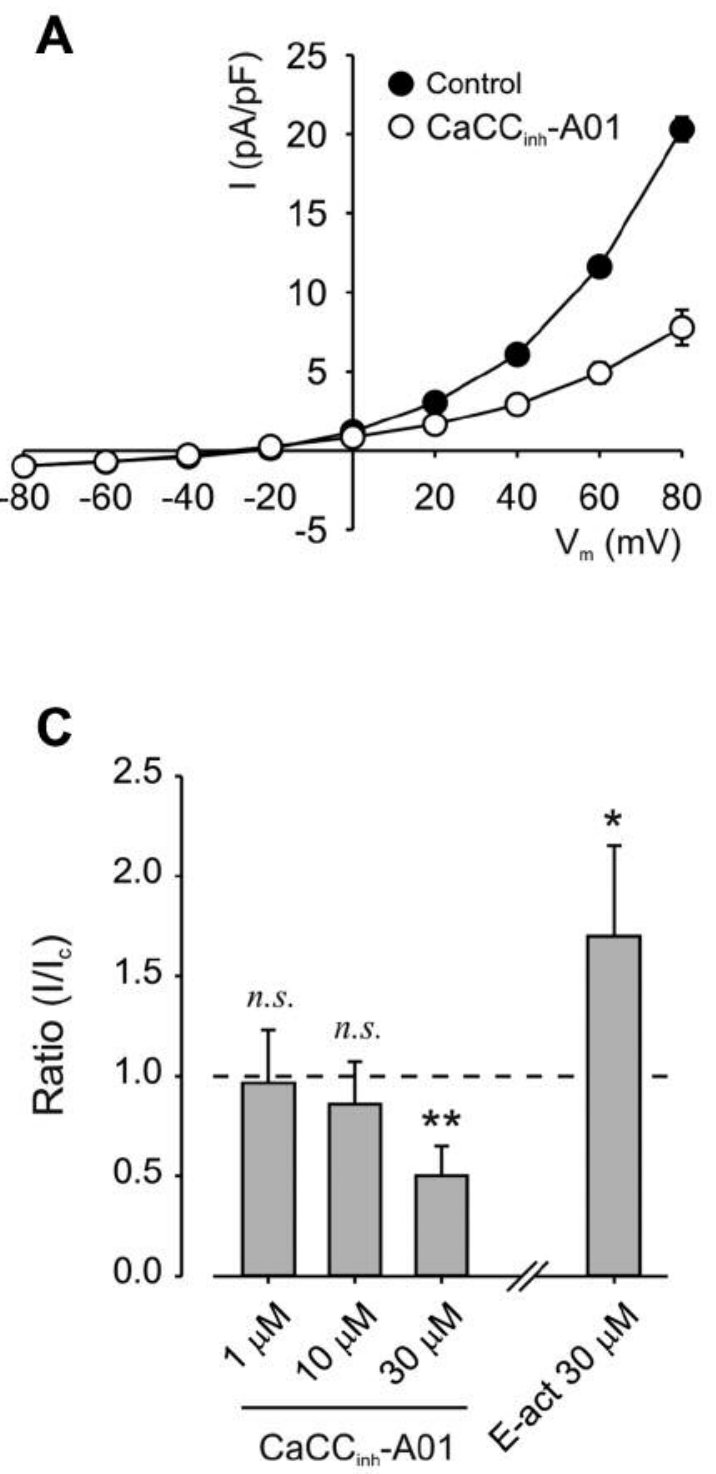

\section{B Control}

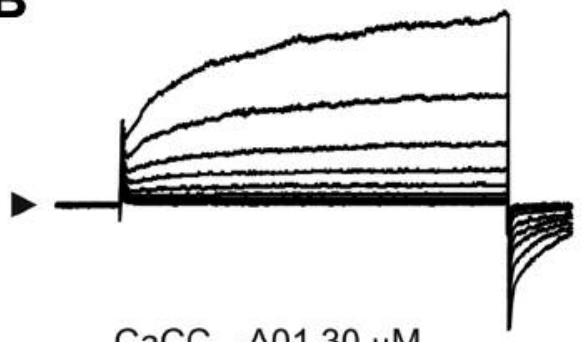

$\mathrm{CaCC}_{\text {inh }}-\mathrm{A} 0130 \mu \mathrm{M}$

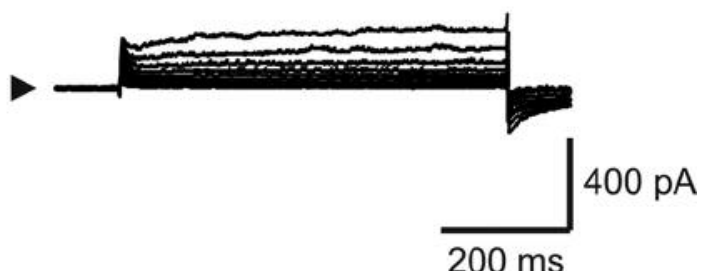

D

\section{Control}

E-act $30 \mu \mathrm{M}$

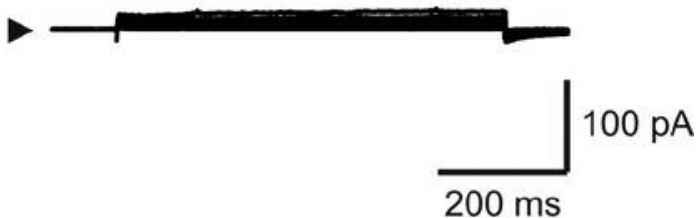

$\mathbf{E}$

$\mathrm{CaCC}_{\text {inh }}-\mathrm{A} 01$

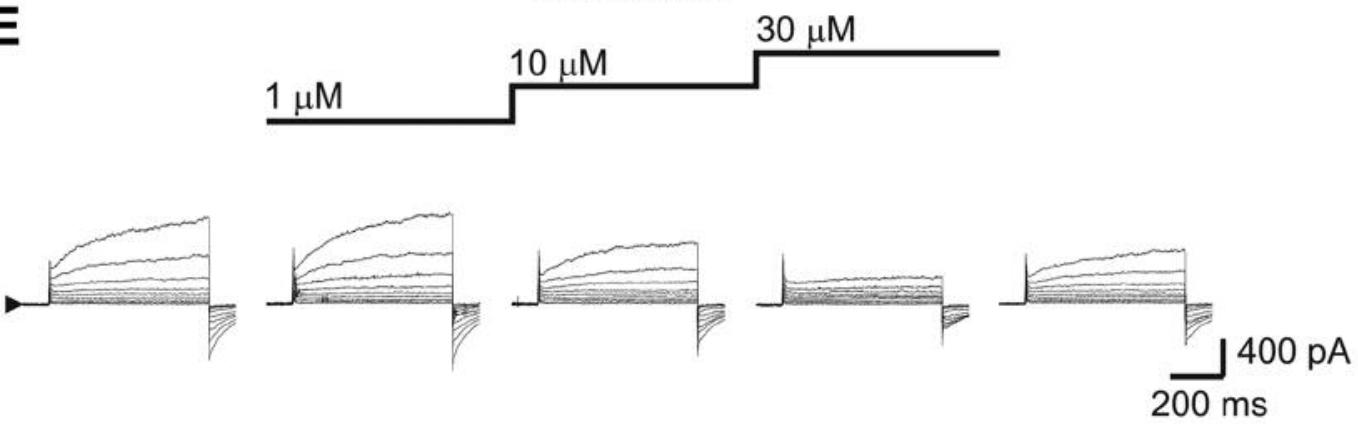

Figure 1. Patch-clamp recordings from GIST-T1 using whole-cell configuration. The cells were voltage-clamped at - $80 \mathrm{mV}$ and were subsequently depolarized for $600 \mathrm{~ms}$ in steps of $20 \mathrm{mV}$ to $+80 \mathrm{mV}\left(\mathrm{A}, \mathrm{B} \text {, and D). In A and B, }\left[\mathrm{Ca}^{2+}\right]_{\text {pip }} \text { was fixed to } 305 \mathrm{nM} \text {, whereas in D [Ca }{ }^{2+}\right]_{\text {pip }}$ was

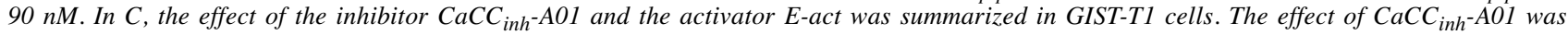
reversible since after withdrawal of the drug the whole-cell current returned the same level as before exposure to the drug $(E)$. Arrowhead indicates zero current line in $B, D$, and E. Mean current was measured between $100 \mathrm{~ms}$ and $500 \mathrm{~ms}$, and *denotes $p<0.05$, **p<0.01.n.s.: Not significant. 
A

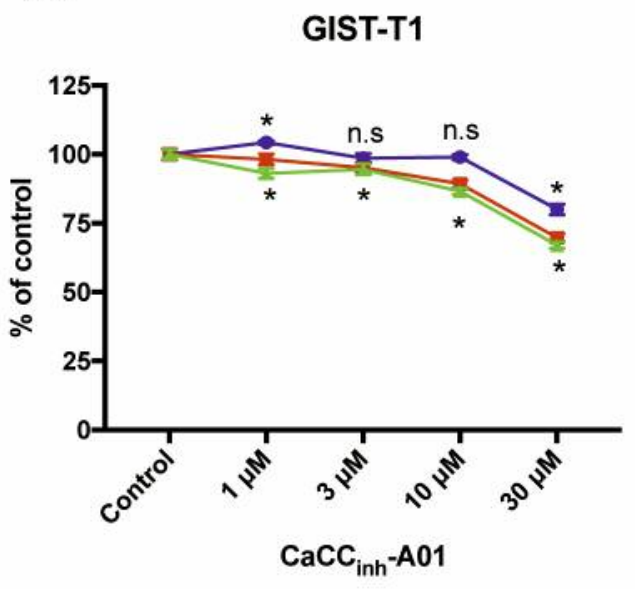

C

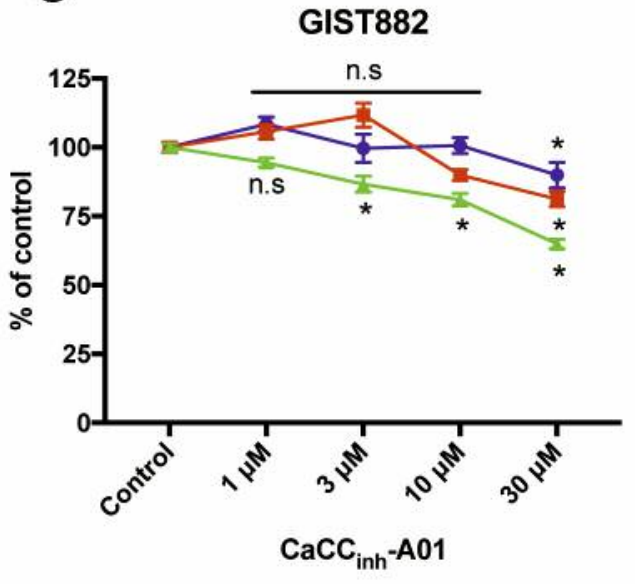

E

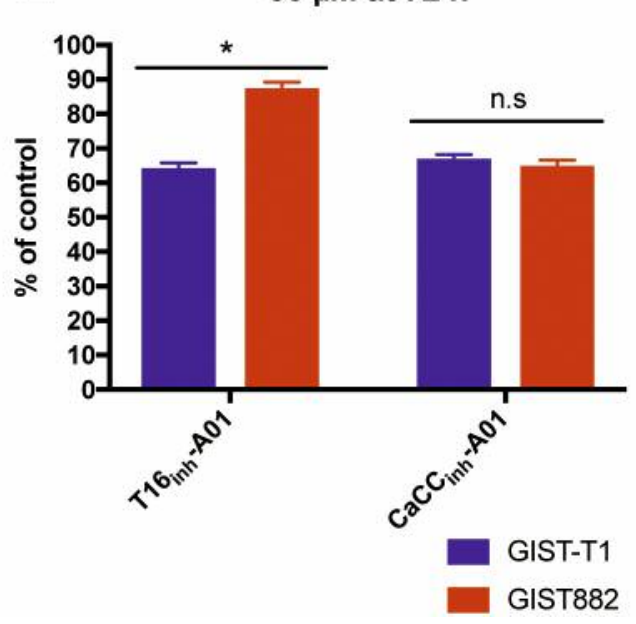

B

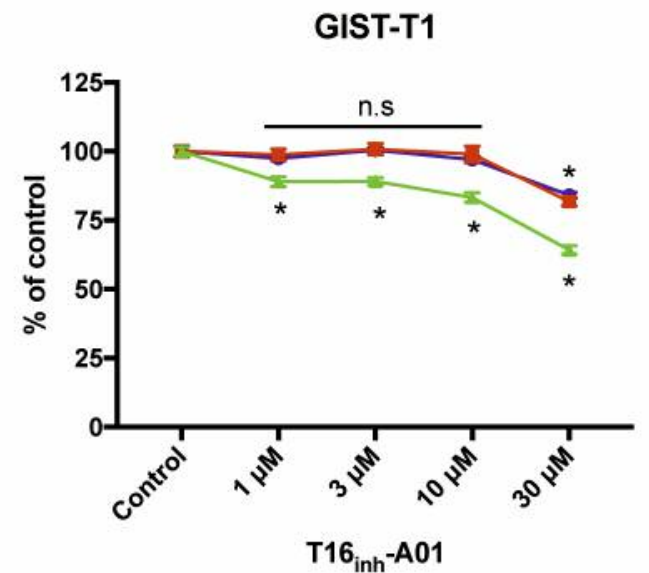

$\rightarrow 24 h$

$-48 \mathrm{~h}$

$-72 \mathrm{~h}$

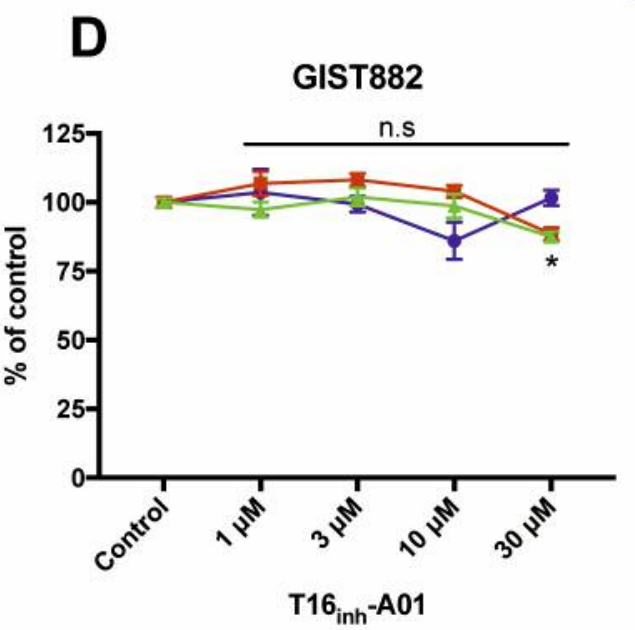

Figure 2. Cell viability of GIST-T1 and GIST882 compared to control

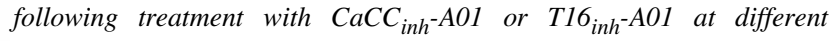
concentrations and time points. (A) Treatment of GIST-T1 with CaCC ${ }_{\text {inh }}{ }^{-}$ A01 significantly reduced viability for all concentrations after $72 h .(B)$

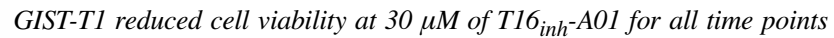
and all concentrations at $72 \mathrm{~h}$. (C) Treatment of GIST882 with CaCC inh $^{-}$ A01 reduced cell viability at all concentrations $>1 \mu M$ at all time points, but only $30 \mu M$ was significant for all time points. (D) Effect of T16 ${ }_{\text {inh }}-A 01$ in GIST882 was significant only at $30 \mu M$ after $72 \mathrm{~h}$ treatment. (E) Comparison of the cell viability effects using the two inhibitors at $72 \mathrm{~h}$ and $30 \mu M$ concentrations in both GIST-T1 and GIST882 cell lines. For A-D, a two-way ANOVA with multiple comparisons Dunnett's test were used. For $E$, $t$-test was used to determine the difference between cell lines. Results represent mean $\pm S E M$ of five wells per condition of representative experiments $(n=3)$. ${ }^{*} p<0.05$. 


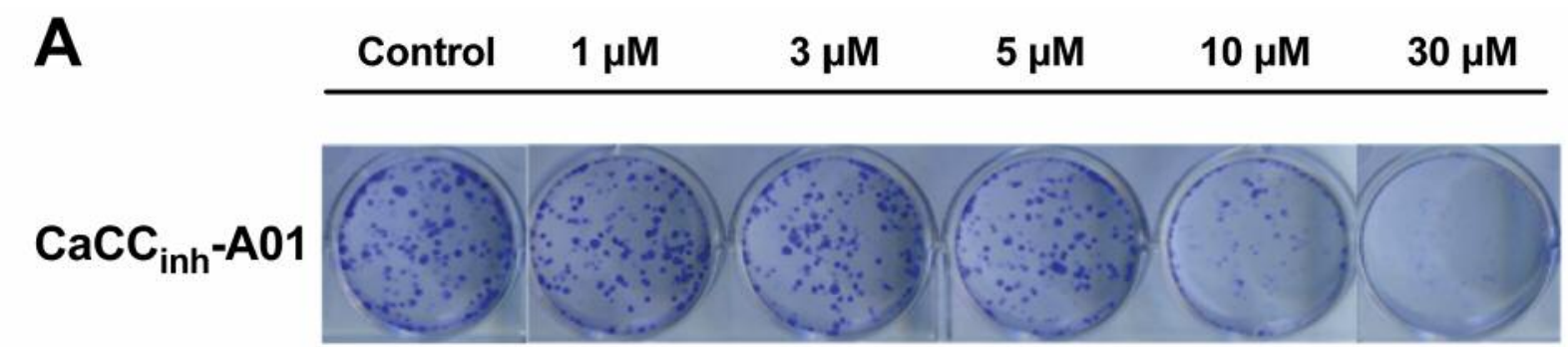

T16 ${ }_{\text {inh }}-\mathrm{A} 01$

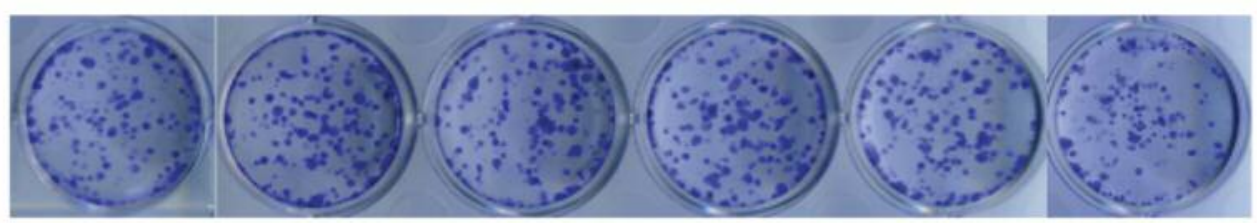

B

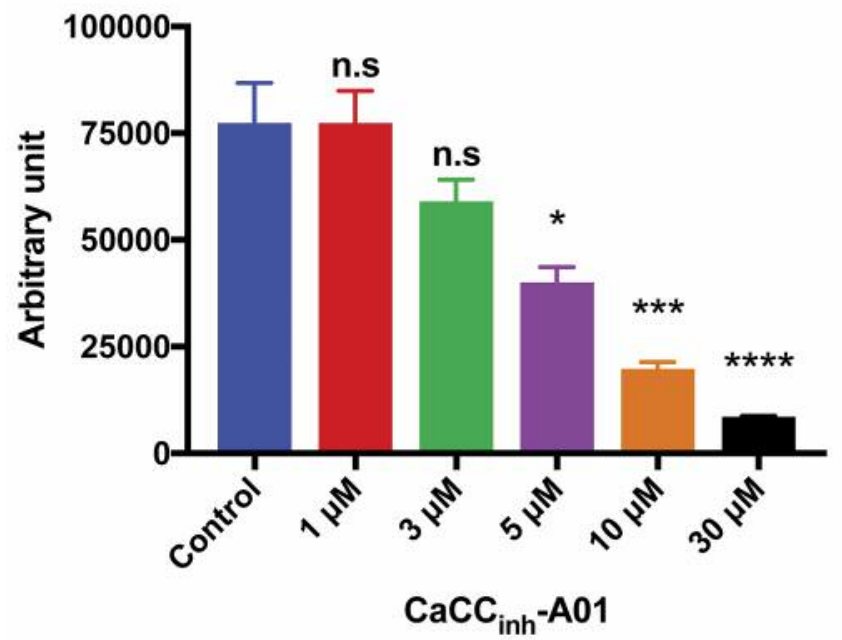

C

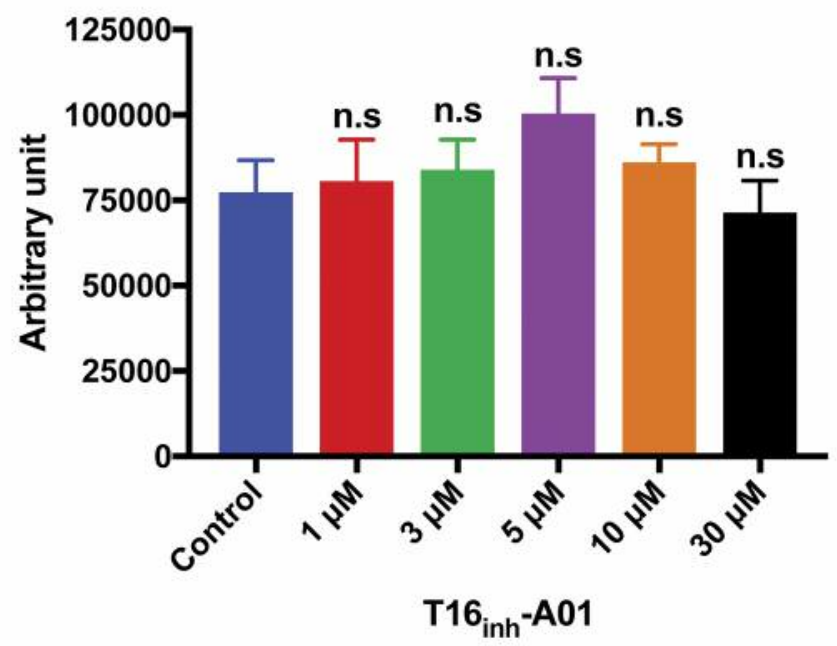

Figure 3. Colony formation assays in GIST-T1 cells. (A) Representative images of colony formation in GIST-T1 cells. Cells treated with various concentrations of CaCCinh-A01 (upper row) or T16inh-A01 (lower row) decreased colony-forming ability. (B) Quantitative values of colony forming ability in $\mathrm{CaCC}_{\text {inh }}$-A01-treated cells, with a significantly reduced colony formation at concentrations $>3 \mu M$. (C) Quantitative values of T16 ${ }_{\text {inh }}{ }^{-}$ A01 treated cells, with no significant change in colony formation. Results represent mean \pm SEM ( $n=3)$. Analysis of variance was done using oneway ANOVA with multiple comparison tests using Dunnett's test. *p $<0.05$, ***p<0.001, ****p<0.0001.

approach as well as biochemical inhibition (27). The antitumoral effect was only achieved in vivo following the use of DOGl knockdown. The effects seen in vitro with biochemical inhibition were attributed to off-target effects, also present in the DOG1 knockdown cell lines. The second study is from our group, in which we used both DOG1

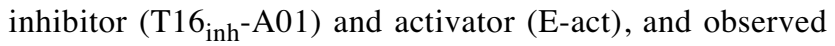
modest effect on viability, proliferation, and apoptosis in vitro, even though we showed that inhibition, using $\mathrm{T} 16_{\text {inh }^{-}}$ A01, could act as a pro-apoptotic effector on early apoptotic GIST48 (an imatinib-resistant cell line) cells (28).
Several potent DOG1 inhibitors now exist, and we have focused on one of the most potent ones possessing antitumoral properties, but also $\mathrm{T} 16_{\mathrm{inh}}$-A01 that was used in our previous study (28). First, we show that chloride currents are inhibited following exposure to $\mathrm{CaCC}_{\mathrm{inh}}-\mathrm{A} 01$, in a dosedependent and reversible manner. At $30 \mu \mathrm{M}$ the DOG1current is inhibited by approximately $60 \%$. In our experiments, we used the whole-cell configuration of the patch-clamp technique. In this setting, intracellular modulators, such as $\mathrm{Ca}^{2+}$, cAMP and inositol triphosphate (IP3) are clamped and equilibrated with the pipette solution 
A

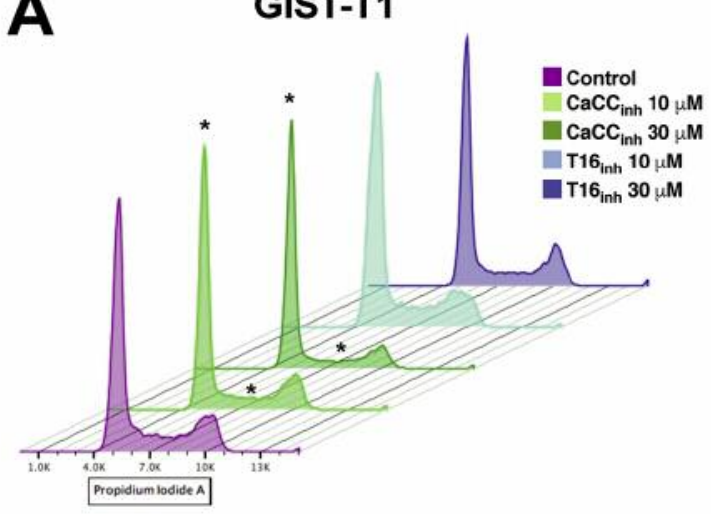

C

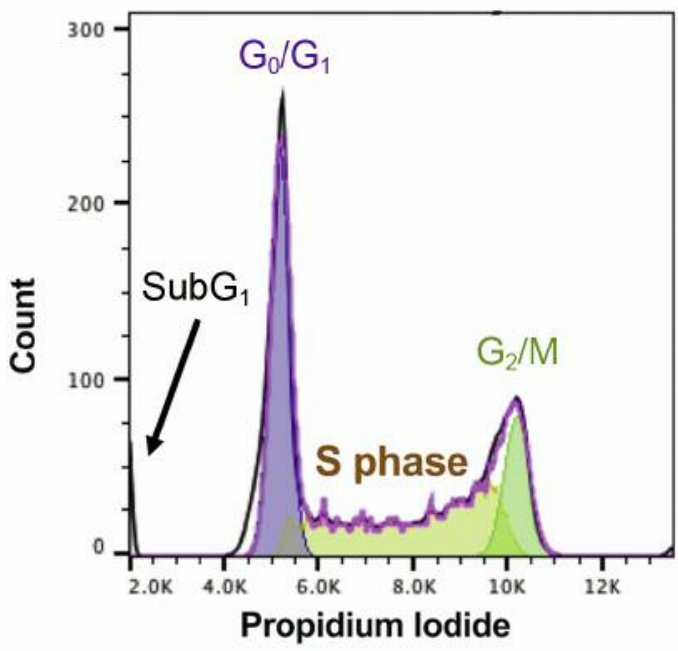

$\mathbf{E}$
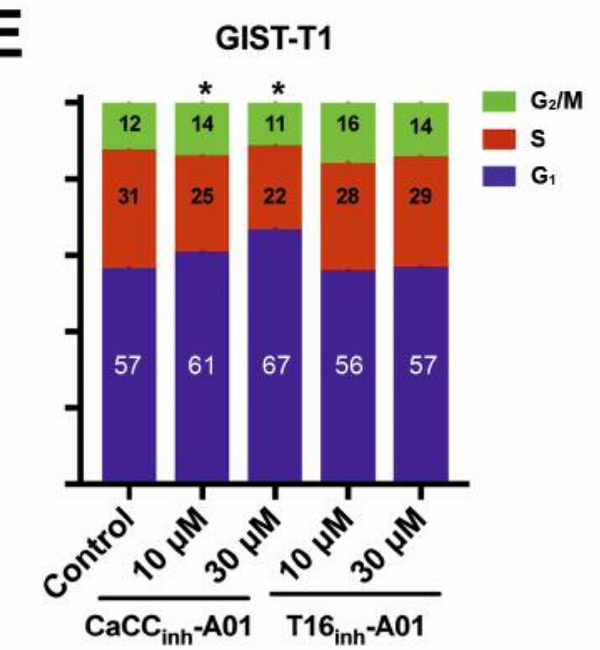

B GIST882

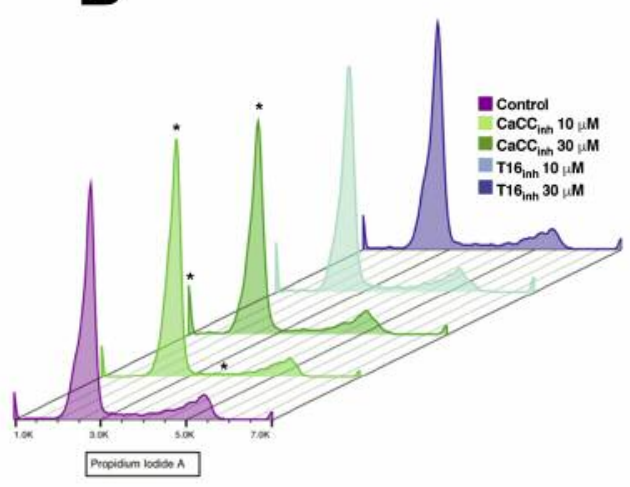

D
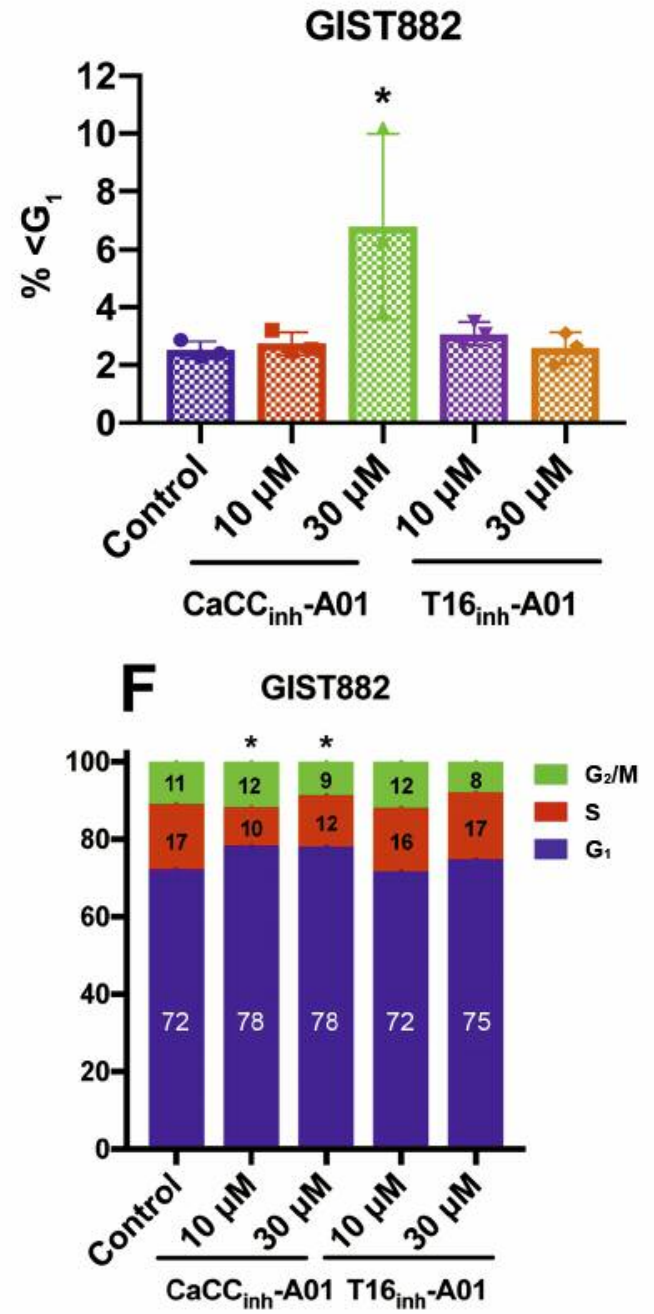

Figure 4. Flow cytometric analysis of the cell cycle. (A) and (B) show a representative histogram from cell cycle analysis, note in $(B)$ definition of the different cell cycle phases. (C) Indicates the different distributions in the histogram. (D) Sub-G analysis of GIST882 cells, shows significant increased

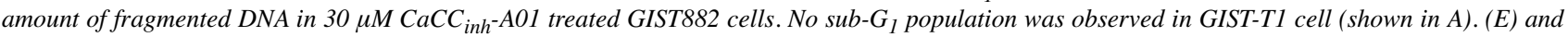
(F) Distribution of the cell-cycle phases in GIST-T1 and GIST882 cells, both demonstrating significant $G_{1}$-cell cycle arrest following treatment with $C_{\text {acCC }}$ inh $-A 01$ at both 10 and $30 \mu \mathrm{M}$ concentrations. Data represent mean $\pm S D$ from three independent experiments. A-B and E-F analysis of variance was determined using two-way ANOVA with multiple comparison using Dunnett's test. For D Kruskal-Wallis test was used. *p<0.05. 
and omitting the potential impact of these modulators. Furthermore, the cells are voltage-clamped, and DOG1current is evaluated at different membrane potentials. DOG1current is dependent on intracellular $\mathrm{Ca}^{2+}$-levels, and in low levels of $\left[\mathrm{Ca}^{2+}\right]_{\mathrm{i}}$ no chloride currents could be seen, well in accordance with our previous findings (28). Our conclusion from this set of experiments and previous finding are that $\mathrm{CaCC}_{\mathrm{inh}}-\mathrm{A} 01$ is a direct blocker of $\mathrm{CaCC}$ in GIST cells.

Secondly, cell viability is decreased in cells exposed to both inhibitors. GIST-T1 was more sensitive to $\mathrm{T}_{1} 6_{\text {inh }}$-A01 treatment compared to GIST882, with only $30 \mu \mathrm{M}$ after 72 $\mathrm{h}$ affecting cell viability significantly. In general, $\mathrm{CaCC}_{\mathrm{inh}^{-}}$ A01 potently reduced cell viability in both cell lines, while $\mathrm{T} 16_{\text {inh }}$-A01 was more cell-specific, reducing viability more in GIST-T1 compared to GIST882. We used fully supplemented medium for viability assays in this study in contrast to another study using serum-starved cells with more potent effects on cell viability of DOG1 inhibition in prostate cancer with $\mathrm{CaCC}_{\mathrm{inh}}$-A01 and $\mathrm{T}_{16} 6_{\text {inh }^{-}}$-A01 inhibitors (23). Using serum-starvation (no FBS added to cell medium), 30 $\mu \mathrm{M} \mathrm{CaCC} \mathrm{inh}_{\text {- }} \mathrm{A} 01$ had the best effect, and reduced cell viability by more than $50 \%$ over a 24 -h time period in GISTT1 cells (data not shown).

To assess the long-term effects of DOG1 inhibition, we used the colony formation assay during 10-14 days prior to readout. In GIST-T1 cells, $\mathrm{CaCC}_{\mathrm{inh}}$ - $\mathrm{A} 01$ strongly reduced the ability to form colonies, from concentrations of $5 \mu \mathrm{M}$ and above while $\mathrm{T} 16_{\text {inh }}$-A01 showed no significant effects on the colony forming ability of the cells. One possible explanation for this is that DOG1 is necessary for long-term cell survival. DOG1 knockdown in GIST in vitro did not lead to significantly reduced proliferation rates, even though such an effect has been demonstrated in a xenograft model in vivo (27). Secondly, degradation of DOG1 protein is ERassociated and does not occur immediately, but can take up to several days (29). Taken together, this might suggest that DOG1 degradation is necessary for long-term cell survival.

We also show that $\mathrm{CaCC}_{\text {inh }}-\mathrm{A} 01$, but not $\mathrm{T}_{16} 6_{\text {inh }}-\mathrm{A} 01$, induces a cell cycle arrest in $\mathrm{G}_{1}$-phase. In addition to cell cycle arrest, we also observed in GIST882, but not GIST-T1, a sub$\mathrm{G}_{1}$ population of cells, indicative of apoptosis. The sub- $\mathrm{G}_{1}$ population was significantly increased in $\mathrm{CaCC}_{\mathrm{inh}}-\mathrm{A} 0130 \mu \mathrm{M}$ treated cells. Only adherent cells were used in this study, which could possibly underestimate the proportion of apoptotic cells.

Even though off-target effects of DOG1 inhibitors cannot be excluded (33), a thorough study using a screening method to identify blockers of $\mathrm{CaCC}$, and specifically DOG1, has identified that DOG1 protein degradation is necessary to achieve antitumoral effect (29). Noteworthy, DOG1-negative cells showed higher viability compared to DOG1-positive cells when exposed to DOG1 inhibitors. It was also shown that protein degradation was ER-associated and that the effect of degradation was observed after 24-48 hours. A study on prostate cancer has shown that DOG1 inhibitors could induce apoptosis in prostate cancer cell lines through upregulating TNF- $\alpha$ signaling (23). TNF- $\alpha$ signaling occured using both siRNA technology and biochemical inhibition using DOG1 inhibitors, suggesting similar mechanisms of action. Taken together, we interpret our findings that the antitumoral effects observed in this study are likely desirable on-target effects, with $\mathrm{CaCC}_{\mathrm{inh}}$-A01 being the most potent inhibitor in inducing antitumoral responses

The effect of the DOG1 inhibitors, not only on chloride currents, but also on DOG1 protein degradation, showed that this occurs after $24 \mathrm{~h}$ of treatment and increases over time (29). The colony formation assay examined the long-term effect on cell survival and showed a large difference between the two. It is likely that this effect is mediated by DOG 1 protein degradation, since DOG1 is involved in proliferation, as it has also been shown in several knockdown models in epithelial cells as well as in GIST $(14,16,27)$. Finally, we also report an effect on cell cycle that is in concordance with previous studies $(29,35)$. The $\mathrm{G}_{1}$-cell cycle arrest leads to slower proliferation of the cells. There was also a difference between the two inhibitors; $\mathrm{CaCC}_{\text {inh }}-\mathrm{A} 01$ induced a statistically significant $\mathrm{G}_{1}$-cell cycle arrest, while $\mathrm{T} 16_{\text {inh }} \mathrm{A} 01$ did not affect the distribution of the cells in the cell cycle. These data fit well with our data on viability and colony formation ability, and further support the notion that DOG1 is likely the mediator of long-term cell growth and survival.

In conclusion, we showed for the first time that DOG1 inhibition has antitumoral effects in the most common mesenchymal tumor of the gut, GIST. Inhibiting DOG1 affects the chloride current, causing $\mathrm{G}_{1}$ cell-cycle arrest, while $\mathrm{CaCC}_{\mathrm{inh}}$-A01 strongly reduces cells ability to form colonies. This is likely mediated via DOG1 protein degradation. The outlined effects of DOG1 inhibition combined with its strong overexpression (>95\%) among GIST patients makes it an attractive approach for the development of novel targeted biochemical GIST therapies.

\section{Conflicts of Interest}

None of the Authors declares a conflict of interest.

\section{Authors' Contribution}

RF, FS, and RB designed the experiments. RF, FS, CX, AZ and RB performed the experiments. RF, FS, CX, and RB performed the data analysis. RF and RB drafted the manuscript. All authors contributed to the interpretation of data, revised the manuscript and approved the final manuscript.

\section{Acknowledgements}

The study was financially supported by the Swedish Research Council, the Swedish Cancer Society, the Swedish Society of Medicine (Bengt Ihre grant), and the Cancer Society in Stockholm. 
Financial support was also provided through the regional agreement on medical training and clinical research (ALF) between the Stockholm County Council and Karolinska Institutet.

\section{References}

1 Mastrangelo G, Coindre JM, Ducimetière F, Dei Tos AP, Fadda E, Blay JY, Buja A, Fedeli U, Cegolon L, Frasson A, RanchèreVince D, Montesco C, Ray-Coquard I and Rossi CR: Incidence of soft tissue sarcoma and beyond: a population-based prospective study in 3 European regions. Cancer 118(21): 53395348, 2012. PMID: 22517534. DOI: 10.1002/cncr.27555

2 Corless CL, Barnett CM and Heinrich MC: Gastrointestinal stromal tumours: origin and molecular oncology. Nat Rev Cancer 11(12): 865-878, 2011. PMID: 22089421. DOI: 10.1038/ nrc3143

3 Blanke CD, Demetri GD, von Mehren M, Heinrich MC, Eisenberg B, Fletcher JA, Corless CL, Fletcher CD, Roberts PJ, Heinz D, Wehre E, Nikolova Z and Joensuu H: Long-term results from a randomized phase II trial of standard- versus higher-dose imatinib mesylate for patients with unresectable or metastatic gastrointestinal stromal tumors expressing KIT. J Clin Oncol 26(4): 620-625, 2008. PMID: 18235121. DOI: 10.1200/ JCO.2007.13.4403

4 West RB, Corless CL, Chen X, Rubin BP, Subramanian S, Montgomery K, Zhu S, Ball CA, Nielsen TO, Patel R, Goldblum JR, Brown PO, Heinrich MC and van de Rijn M: The novel marker, DOG1, is expressed ubiquitously in gastrointestinal stromal tumors irrespective of KIT or PDGFRA mutation status. Am J Pathol 165(1): 107-113, 2004. PMID: 15215166. DOI: 10.1016/S0002-9440(10)63279-8

5 Schwab M: Amplification of oncogenes in human cancer cells. Bioessays 20(6): 473-479, 1998. PMID: 9699459. DOI: 10.1002/ (SICI)1521-1878(199806)20:6<473::AID-BIES5>3.0.CO;2-N

6 Li J, Zhang H, Lu Y, Chen Z and Su K: Presence of PDGFRA and DOG1 mutations in gastrointestinal stromal tumors among Chinese population. Int J Clin Exp Pathol 8(5): 5721-5726, 2015. PMID: 26191287.

7 Huang F, Rock JR, Harfe BD, Cheng T, Huang X, Jan YN and Jan LY: Studies on expression and function of the TMEM16A calcium-activated chloride channel. Proc Natl Acad Sci USA 106(50): 21413-21418, 2009. PMID: 19965375. DOI: 10.1073/ pnas.0911935106

8 Hartzell C, Putzier I and Arreola J: Calcium-activated chloride channels. Annu Rev Physiol 67: 719-758, 2005. PMID: 15709976. DOI: 10.1146/annurev.physiol.67.032003.154341

9 Paulino C, Kalienkova V, Lam AKM, Neldner Y and Dutzler R: Activation mechanism of the calcium-activated chloride channel TMEM16A revealed by cryo-EM. Nature 552(7685): 421-425, 2017. PMID: 29236691. DOI: 10.1038/nature24652

10 Choi EJ, Yun JA, Jabeen S, Jeon EK, Won HS, Ko YH and Kim SY: Prognostic significance of TMEM16A, PPFIA1, and FADD expression in invasive ductal carcinoma of the breast. World $\mathrm{J}$ Surg Oncol 12: 137, 2014. PMID: 24886289. DOI: 10.1186/ 1477-7819-12-137

11 Kulkarni S, Bill A, Godse NR, Khan NI, Kass JI, Steehler K, Kemp C, Davis K, Bertrand CA, Vyas AR, Holt DE, Grandis JR, Gaither LA and Duvvuri U: TMEM16A/ANO1 suppression improves response to antibody-mediated targeted therapy of EGFR and HER2/ERBB2. Genes Chromosomes Cancer 56(6): 460-471, 2017. PMID: 28177558. DOI: $10.1002 /$ gcc.22450
12 Ubby I, Bussani E, Colonna A, Stacul G, Locatelli M, Scudieri P, Galietta La and Pagani F: TMEM16A alternative splicing coordination in breast cancer. Mol Cancer 12: 75, 2013. PMID: 23866066. DOI: 10.1186/1476-4598-12-75

13 Britschgi A, Bill A, Brinkhaus H, Rothwell C, Clay I, Duss S, Rebhan M, Raman P, Guy CT, Wetzel K, George E, Popa MO, Lilley S, Choudhury H, Gosling M, Wang L, Fitzgerald S, Borawski J, Baffoe J, Labow M, Gaither LA and Bentires-Alj M: Calcium-activated chloride channel ANO1 promotes breast cancer progression by activating EGFR and CAMK signaling. Proc Natl Acad Sci USA 110(11): E1026-1034, 2013. PMID: 23431153. DOI: $10.1073 /$ pnas.1217072110

14 Jia L, Liu W, Guan L, Lu M and Wang K: Inhibition of calciumactivated chloride channel ANO1/TMEM16A suppresses tumor growth and invasion in human lung cancer. PLoS One 10(8): e0136584, 2015. PMID: 26305547. DOI: 10.1371/journal. pone. 0136584

15 Mroz MS and Keely SJ: Epidermal growth factor chronically upregulates $\mathrm{Ca}(2+)$-dependent $\mathrm{Cl}(-)$ conductance and TMEM16A expression in intestinal epithelial cells. J Physiol 590(Pt 8): 19071920, 2012. PMID: 22351639. DOI: 10.1113/ jphysiol.2011.226126

16 Sui Y, Sun M, Wu F, Yang L, Di W, Zhang G, Zhong L, Ma Z, Zheng J, Fang $X$ and Ma T: Inhibition of TMEM16A expression suppresses growth and invasion in human colorectal cancer cells. PLoS One 9(12): e115443, 2012. PMID: 25541940. DOI: 10.1371/journal.pone.0115443

17 Duvvuri U, Shiwarski DJ, Xiao D, Bertrand C, Huang X, Edinger RS, Rock JR, Harfe BD, Henson BJ, Kunzelmann K, Schreiber R, Seethala RS, Egloff AM, Chen X, Lui VW, Grandis JR and Gollin SM: TMEM16A induces MAPK and contributes directly to tumorigenesis and cancer progression. Cancer Res 72(13): 3270-3281, 2012. PMID: 22564524. DOI: 10.1158/000 8-5472.CAN-12-0475-T

18 Ruiz C, Martins JR, Rudin F, Schneider S, Dietsche T, Fischer CA, Tornillo L, Terracciano LM, Schreiber R, Bubendorf L and Kunzelmann K: Enhanced expression of ANO1 in head and neck squamous cell carcinoma causes cell migration and correlates with poor prognosis. PLoS One 7(8): e43265, 2012. PMID: 22912841. DOI: 10.1371/journal.pone.0043265

19 Shiwarski DJ, Shao C, Bill A, Kim J, Xiao D, Bertrand CA, Seethala RS, Sano D, Myers JN, Ha P, Grandis J, Gaither LA, Puthenveedu MA and Duvvuri U: To "grow" or "go": TMEM16A expression as a switch between tumor growth and metastasis in SCCHN. Clin Cancer Res 20(17): 4673-4688, 2014. PMID: 24919570. DOI: 10.1158/1078-0432.CCR-14-0363

20 Liu F, Cao QH, Lu DJ, Luo B, Lu XF, Luo RC and Wang XG: TMEM16A overexpression contributes to tumor invasion and poor prognosis of human gastric cancer through TGF- $\beta$ signaling. Oncotarget 6(13): 11585-11599, 2015. PMID: 25839162. DOI: $10.18632 /$ oncotarget.3412

21 Liu J, Liu Y, Ren Y, Kang L and Zhang L: Transmembrane protein with unknown function 16A overexpression promotes glioma formation through the nuclear factor- $\mathrm{kB}$ signaling pathway. Mol Med Rep 9(3): 1068-1074, 2014. PMID: 24401903. DOI:10.3892/mmr.2014.1888

22 Liu W, Lu M, Liu B, Huang Y and Wang K: Inhibition of $\mathrm{Ca}(2+)$-activated $\mathrm{Cl}(-)$ channel ANO1/TMEM16A expression suppresses tumor growth and invasiveness in human prostate carcinoma. Cancer Lett 326(1): 41-51, 2012. PMID: 22820160. DOI: $10.1016 /$ j.canlet.2012.07.015 
23 Song Y, Gao J, Guan L, Chen X and Wang K: Inhibition of ANO1/TMEM16A induces apoptosis in human prostate carcinoma cells by activating TNF- $\alpha$ signaling. Cell Death Dis 9(6): 703, 2018. PMID: 29899325. DOI: 10.1038/s41419-0180735-2

24 Bill A, Gutierrez A, Kulkarni S, Kemp C, Bonenfant D, Voshol H, Duvvuri U and Gaither LA: ANO1/TMEM16A interacts with EGFR and correlates with sensitivity to EGFR-targeting therapy in head and neck cancer. Oncotarget 6(11): 9173-9188, 2015. PMID: 25823819. DOI: 10.18632/oncotarget.3277

25 Cao Q, Liu F, Ji K, Liu N, He Y, Zhang W and Wang L: MicroRNA-381 inhibits the metastasis of gastric cancer by targeting TMEM16A expression. J Exp Clin Cancer Res 36(1): 29, 2017. PMID: 28193228. DOI: 10.1186/s13046-017-0499-Z

26 Li Q, Zhi X, Zhou J, Tao R, Zhang J, Chen P, Røe OD, Sun L and Ma L: Circulating tumor cells as a prognostic and predictive marker in gastrointestinal stromal tumors: a prospective study. Oncotarget 7(24): 36645-36654, 2016. PMID: 27153560. DOI: 10.18632/oncotarget.9128

27 Simon S, Grabellus F, Ferrera L, Galietta L, Schwindenhammer B, Mühlenberg $T$, Taeger G, Eilers G, Treckmann J, Breitenbuecher F, Schuler M, Taguchi T, Fletcher JA and Bauer S: DOG1 regulates growth and IGFBP5 in gastrointestinal stromal tumors. Cancer Res 73(12): 3661-3670, 2013. PMID: 23576565. DOI: 10.1158/0008-5472.CAN-12-3839

28 Berglund E, Akcakaya P, Berglund D, Karlsson F, Vukojević V, Lee L, Bogdanović D, Lui WO, Larsson C, Zedenius J, Fröbom $\mathrm{R}$ and Bränström R: Functional role of the $\mathrm{Ca}(2)(+)$-activated $\mathrm{Cl}(-)$ channel DOG1/TMEM16A in gastrointestinal stromal tumor cells. Exp Cell Res 326(2): 315-325, 2014. PMID: 24825187. DOI: 10.1016/j.yexcr.2014.05.003

29 Bill A, Hall ML, Borawski J, Hodgson C, Jenkins J, Piechon P, et al: Small molecule-facilitated degradation of ANO1 protein: a new targeting approach for anticancer therapeutics. J Biol Chem 289(16): 11029-11041, 2014. PMID: 24599954. DOI: 10.1074/jbc.M114.549188
30 Ji Q, Guo S, Wang X, Pang C, Zhan Y, Chen Y and An H: Recent advances in TMEM16A: Structure, function, and disease. J Cell Physiol (6): 7856-7873, 2019. PMID: 30515811. DOI: $10.1002 /$ jcp. 27865

31 Berglund E, Berglund D, Akcakaya P, Ghaderi M, Daré E, Berggren PO, Köhler M, Aspinwall CA, Lui WO, Zedenius J, Larsson $\mathrm{C}$ and Bränström R: Evidence for $\mathrm{Ca}(2+)$-regulated ATP release in gastrointestinal stromal tumors. Exp Cell Res 319(8): 1229-1238, 2013. PMID: 23499741. DOI: 10.1016/j.yexcr. 2013.03.001

32 Hamill OP, Marty A, Neher E, Sakmann B and Sigworth FJ: Improved patch-clamp techniques for high-resolution current recording from cells and cell-free membrane patches. Pflugers Arch 391(2): 85-100, 1981. PMID: 6270629.

33 Wang H, Zou L, Ma K, Yu J, Wu H, Wei M and Xiao Q: Cellspecific mechanisms of TMEM16A Ca. Mol Cancer 16(1): 152, 2017. PMID: 28893247. DOI: 10.1186/s12943-017-0720-x

34 Boedtkjer DM, Kim S, Jensen AB, Matchkov VM and Andersson KE: New selective inhibitors of calcium-activated chloride channels - T16A(inh) - A01, CaCC(inh) -A01 and MONNA - what do they inhibit? Br J Pharmacol 172(16): 41584172, 2015. PMID: 26013995. DOI: 10.1111/bph.13201

35 Guan L, Song Y, Gao J and Wang K: Inhibition of calciumactivated chloride channel ANO1 suppresses proliferation and induces apoptosis of epithelium originated cancer cells. Oncotarget 7(48): 78619-78630, 2016. PMID: 27732935. DOI:10.18632/oncotarget.12524 